\title{
Van profeet tot patiënt: visies op kunstenaarschap in de negentiende eeuw
}

Kunstenaarschap is aangeboren. Je bent kunstenaar of je bent het niet. Fietsen en broodbakken kun je leren, maar dichten en schilderen is alleen voor iemand weggelegd die de beschikking heeft over een bijzonder, aangeboren talent. Dit is een visie die ook nu nog, denk ik, door een groot publiek wordt gedeeld. Door deze visie schemert soms ook het idee dat kunstenaars weliswaar bijzondere, maar daardoor tegelijk ook een beetje eigenaardige, gekke mensen zijn.

In feite is deze kijk op kunstenaarschap in termen van 'bijzonder' en zelfs van 'gek' nog maar tamelijk recent. Pas aan het eind van de achttiende eeuw gingen filosofen en dichters over het kunstenaarschap denken in termen van aangeboren hoogst bijzondere kwaliteiten. Rond 1800 begon dichterschap verbonden te worden aan het concept genialiteit. De dichter werd nu gezien als een begenadigde geest die spontaan, in een roes zijn gedichten op papier zette. In een staat van grote opwinding zou hij met behulp van zijn verbeelding het gedicht in één klap op papier zetten. $\mathrm{Al}$ scheppende werd hij boven zichzelf uitgetild en steeg hij als een montgolfière op in de wolken. De dichter rijmde niet zomaar wat bij elkaar: hij schouwde; hij zag verder dan de gewone sterveling.

De ontwikkeling van deze visie kan in direct verband gezien worden met het proces van autonomie in het artistieke domein, dat inmiddels op gang was gekomen. Het maken van poëzie, van literatuur, van kunst kreeg daardoor behoefte aan een eigen, onafhankelijke legitimatie. En het beeld van de geniale, tot metafysische hoogte opstijgende kunstenaar kon daarin voorzien.
Naarmate de negentiende eeuw vorderde, vatte steeds sterker de gedachte post dat kennis niet vergaard werd door te schouwen, door een verbinding te leggen met het metafysische, maar eenvoudig door te kijken, te meten, te tellen, hypotheses op te stellen en te experimenteren. En zo begon de kunstenaar wat van zijn uitverkoren positie als profeet te verliezen. De negentiende eeuw is de tijd van het categoriseren en van het definiëren; van het afgrenzen van het normale tegen het abnormale. In de geneeskunde waren wetenschappers enthousiast lijstjes aan het maken van kenmerken van verschillende typen mensen die zich zouden onderscheiden van de gewone, normale mens, zoals het type van de alcoholist, de misdadiger en de prostituee. Ook het genie ging onder het mes. Wat waren de kenmerken van het genie? Op welke punten onderscheidde hij zich van de niet-geniale en dus 'normale' medemens? Het verband met krankzinnigheid lag voor de hand. Dat verband was aan het begin van de negentiende eeuw al door de filosoof Schopenhauer gesuggereerd en al in de klassieke oudheid door Plato naar voren gebracht. Dit idee van kunstenaarschap als een vorm van geestesziekte vatte nu ook binnen de medische wetenschap post. Bij de diagnostiek van het genie (de kunstenaar) werd gebruik gemaakt van een drietal aanwezige medische concepten: de temperamentenleer, neurasthenie en degeneratie.

\section{Temperamentenleer}

Kunstenaars, was de gedachte, bezaten overwegend een nerveus temperament. Dat, meenden artsen, is een gestel waarbij 
het zenuwstelsel overontwikkeld is, maar dat - als gevolg daarvan - weinig bloed heeft en dus weinig kracht. Deze lichamelijke aanleg zou samengaan met een hele reeks lichamelijke en psychische eigenschappen: lichte ogen, licht haar, een fijne lange hals, een hartvormig gezicht, sprekende gelaatstrekken en een tengere gestalte. Het gevoelsleven van het nerveuze temperament is diep. Het type vat de dingen gauw zwaar op en vervalt daardoor gemakkelijk tot melancholie. In het algemeen is het vatbaar voor ziekten van het zenuwstelsel, van hoofdpijn tot krankzinnigheid toe. De intellectuele vermogens zijn doorgaans groot: genialiteit en een artistieke aanleg zouden dan ook vooral voorkomen bij dit temperament.

\section{Neurasthenie en degeneratie}

In de steeds grotere concentratie van artsen op de zenuwen en op mogelijke ziekten van het zenuwstelsel, in combinatie met een toenemende angst voor verslapping van de westerse samenleving, ontwikkelde de Amerikaanse arts George Miller Beard aan het eind van de jaren zestig van de negentiende eeuw een nieuw ziektefenomeen: neurasthenie. Het zou hier gaan om oververmoeidheid en verzwakking van de zenuwen als direct gevolg van de hectische, veeleisende moderne maatschappij, vooral in de stad.

Neurasthenie werd door artsen opgevat als een eerste fase in een proces van degeneratie. Daarmee raakte het verschijnsel neurasthenie geïntegreerd met een concept dat al langer in en buiten de medische wereld opgeld deed: degeneratie. Degeneratie werd gezien als een storing in het erfelijke transmissiesysteem. In plaats van op een gezonde manier kenmerken van de vorige generaties door te geven, zouden nu in de negentiende eeuw in toenemende mate verkeerde eigenschappen worden overgeërfd. Hierdoor begonnen geslachten zienderogen te vervallen, zowel lichamelijk als psychisch, om ten slotte compleet uit te sterven.

Er ontstond een hausse van belangstelling voor dit angstaanjagende en ongrijpbare fenomeen van degeneratie, vooral in Frankrijk. In de rijke woekering aan degeneratietheorieën die er spoedig ontstond, was het niet moeilijk om ook een plaatsje te vinden voor het genie. Dat deed de Italiaanse arts Cesare Lombroso. In 1864 publiceerde hij zijn spraakmakende boek "Genio e folia". Vele uitgebreide herdrukken zouden volgen en vertalingen in het Frans, Duits, Engels en ook in het Nederlands.

Wat deed Lombroso? Hij stelde een lange lijst op met kenmerken van het genie, lichamelijke en psychische, en daar zocht hij handenvol voorbeelden bij. Verder presenteerde hij genialiteit als een vorm van degeneratie, door hem aangeduid als atavisme. Het genie is iets onnatuurlijks, iets gedegenereerds zegt Lombroso. De natuur streeft namelijk naar het harmonieuze gemiddelde, naar het normale. Het abnormale genie moet beschouwd worden als de laatste opflikkering van een degenererend geslacht. Het genie krijgt bij hem dan ook kenmerken van de 'dégénéré'. Lombroso noemt onder andere: onregelmatige tanden, asymmetrie in het gezicht en in de schedel, en vroegtijdige kaalheid. Psychologisch staat het er met het genie ook niet al te best voor: hij heeft geen moreel gevoel, hij is egocentrisch, ijdel en impulsief. Wel bezit hij een grote esthetische ontvankelijkheid. Hij leeft op zijn gevoel en zijn zenuwen en niet zelden eindigt hij krankzinnig.

Lombroso's schets van het genie laat zien hoe in feite toch nog veel ingrediënten van het oude achttiende- en negentiendeeeuwse genieconcept daarin behouden zijn gebleven: niet alleen het idee dat er überhaupt iets als het genie zou bestaan, maar ook de gedachte aan de uitzonder- 
lijkheid en het aangeboren zijn ervan, en aan het scheppen als een spontane, intuïtieve handeling. Deze trekken vertaalde hij in medische termen. Bij Lombroso is de dichter niet meer de door God uitverkorene, maar zo niet een gevaarlijke dan toch op zijn minst een immorele en ijdele gek.

Lombroso's theorie sloeg aan, maar riep onmiddellijk ook veel discussie op, zeker bij vakgenoten. Niettemin vond Lombroso's kerngedachte - de identificatie van genialiteit met krankzinnigheid - grote weerklank, zowel binnen als buiten de wetenschap. Dat kwam niet alleen omdat het hier om een oud verband ging dat al door filosofen als Plato en Schopenhauer was gelegd, maar vooral omdat 'genie' per definitie de betekenis in zich draagt van: ongewoon, anders dan de norm, en dus al gauw van abnormaal, ziek, krankzinnig. Voor wie ervan uitging dat genieën echt bestonden, en dat deed men, maar niet meer wenste te denken in de richting van God of van de metafysica, lag een pathologische invulling voor de hand.

Uiteraard liet deze visie op genialiteit de kunstenaars zelf niet onberoerd. Medische concepten en begrippen kwamen tot hen uit de eerste, tweede of zoveelste hand, en gingen, voor wie daar ook maar enigszins gevoelig voor was, deel uitmaken van hun zelfbeeld. Wetenschappelijke autoriteiten dwongen hen om in een spiegel te kijken en wat die spiegel liet zien was een zenuwpatiënt. In zijn opstel 'Literatuur-fyziologie' uit 1888 gaf de Nederlandse schrijver Lodewijk van Deyssel zijn visie op de kunstenaar, en dus impliciet ook op zichzelf. Hij deed dat in de volgende bewoordingen:

'... alle kunstenaars en groote denkers zijn neurasthenici, en het 'genie', de 'artisticiteit' is, zoolang de wereld bestaat, geweest en zal altijd blijven: een toestand van het zenuwgestel in het men- schen-organisme, die de pathologische terminologie 'abnormaal' noemt, dat wil zeggen: afwijkend van den norm, en gelijkend op toestanden die men bij 'krankzinnigen' en 'misdadigers' aantreft.'

Van Deyssel schakelt hier genialiteit en zenuwziekte aan elkaar. In zijn ogen zijn beide noodzakelijk met elkaar verbonden. Hij laat ook een medische vakterm vallen: 'neurasthenicus'. Het genie is abnormaal en zijn zenuwziekte ligt dicht bij de geestesgesteldheid van andere abnormale categorieën die in de psychiatrische handboeken te vinden zijn, zoals die van de misdadiger, zegt hij.

\section{Het zelfbeeld van de kunstenaar}

Zwakke zenuwen, overgevoeligheid en onvoorspelbare stemmingswisselingen werden nu ook voor kunstenaars zelf, keiharde bewijzen van een artistieke aanleg. Bij een aantal was het zelfbeeld een regelrechte flirt met de pathologie. Zij dachten over zichzelf in medische termen: als zenuwlijders, als neurasthenici, als 'dégénérés superieurs'. Ziek, zwak, zenuwachtig, zwaarmoedig - Kloos, Emants, Aletrino, Van Deyssel, Van Eeden, Coenen - ze waren het allemaal, in elk geval naar hun eigen zeggen. In hun brieven regent het klachten over en weer: niet goed geslapen, de stofwisseling laat te wensen over, een totaal gevoel van zwakte, depressiviteit; het wordt allemaal royaal op tafel gelegd. Het is niets om je over te schamen, integendeel, het zijn de stigmata van de ware kunstenaar. En wanneer eindnegentiende-eeuwse schrijvers in hun werk kunstenaars uitbeelden, dan voorzien zij hem (want doorgaans gaat het om mannelijke personages) van soortgelijke, naar het ziekelijke neigende eigenschappen. 


\section{Wisselwerking tussen literatuur en medische wetenschap}

Wel zien we in die literaire uitbeelding een paar sprekende verschillen met de medische handboeken. In de literaire presentatie is de kunstenaar vaak begiftigd met een bijzonder treffend psychologisch inzicht. Intuïtief doorziet hij de diepere gevoelens en onderliggende motieven van de mensen die hij ontmoet. De kunstenaar is van nature een begenadigd psycholoog. Schrijvers geven ook een andere waardering van neurasthenie. Voor hen is het, zoals voor artsen, geen gevaarlijk teken van verslapping van de negentiende-eeuwse samenleving, maar een medisch gediagnosticeerde mogelijkheid om vorm te geven aan hun antiburgerlijke levensstijl en zich als kunstenaars te onderscheiden. Ook hun kijk op de gedegenereerde kunstenaarsaanleg is een andere dan die van de medici. Wel spoort hij met de toen vigerende visie op de eigen tijd, het fin de siècle, als een periode waarin een vermoeide eeuw op zijn eind liep. Maar als kinderen van die stervende eeuw waren zij, kunstenaars, juist door hun overgevoelige verfij- ning in staat hun gezondere voorgangers te overtreffen. Paradoxaal genoeg was in hun ogen degeneratie artistieke vooruitgang.

Deze snelle historische schets laat zien dat in de cultuur een dynamische wisselwerking plaatsvindt tussen literatuur en wetenschap. Artsen nemen het genie-concept over van dichters en filosofen en kleden het in een eigentijds wetenschappelijk jasje. Vervolgens nemen schrijvers uit de eerste, de tweede of de zoveelste hand kennis van deze wetenschappelijke inzichten in het kunstenaarschap en gaan zij deze in hun creatieve werk en in hun literaire beschouwingen verwerken. De cirkel is rond.

Mary Kemperink

De auteur:

Prof. dr. M.G. Kemperink is sinds 1 oktober 2008 hoogleraar moderne Nederlandse letterkunde, in het bijzonder de relatie tussen literatuur en wetenschap. $Z i j$ is werkzaam aan de afdeling Nederlandse Taal en Cultuur van de Rijksuniversiteit Groningen. Zij is gespecialiseerd in het fin de siècle en heeft regelmatig over het proza, de poëzie en het toneel van deze periode gepubliceerd (M.G.Kemperink @rug.nl). 